\title{
Psychopharmacological Aspects of Catha Edulis (Khat) and Consequences of Long Term Use: A Review
}

\author{
Nasir Tajure Wabel ${ }^{1}$
}

\section{ÖZET:}

Catha edulis (gat)'ın psikofarmakolojik yönleri ve uzun dönem kullanımının sonuçları: Bir gözden geçirme

Catha edulis (gat) Afrika boynuzunda yaygın olarak yetiștirilen bir bitkidir. Yaprakları yerli halk tarafından uyarıcı etkisi sebebi ile çig̃nenmektedir. Bu gözden geçirmenin amacı birçok bilimsel makaleden elde edilen bilgiler ıșIg̃ında gat'ın psikofarmakolojik yönlerini ve uzun dönem kullanımın sonuçlarını özetlemektir. Ben, pek çok bilimsel dergiden veri topladım. Pubmed, Medline, Hinary, Google arama, Cochrane ve EMBASE gibi veritabanlarından Catha edulis (gat)'in merkezi sinir sistemine etkileri, farmakolojik etkisi ve uzun dönem kullanımının sonuçları da dahil olmak üzere farklı yönleriyle ilgili literatür tarandı. Farklı kaynaklardan farklı araștırma sonuçları gat'ın şizofreniform bozuklug̃a, maniye ve daha az sıklıkla depresyona sebep oldug̃u ve sag̃lık ve sosyoekonomik koșullar üzerinde olumsuz etkileri oldug̃u gösterilmiștir. Gat'ın çig̃nenirken ortaya çıkan etkilerinin çog̃u yapısal olarak amfetamine benzer olan fenilalkilaminler; katinon ve katinden kaynaklanmaktadır. Bu temsiller hemen her defasında kendine zarar veya dig̃erlerine zarar ile ilișkilidir. Gatın tüketimde doz amfetaminlere zıt olarak kişiyle sınırlıdır. Bu nedenle gatın aşırı kullanımı sonucu ortaya çıkan toksik psikoz amfetaminden daha az sıklıkla görülür. Gatın fazlaca kullanılması psikotik bozukluk ve sosyoekonomik zararlı sonuçlar gibi deg̃işik bozuklukların ortaya çıkmasında sorumludur. Klinisyenlerin, hastalarının ve genel halkın gat çig̃nemenin zararlı etkileri hakkında farkındalıg̃ı arttırmaları önemlidir.

Anahtar sözcükler: gat, catha edulis, farmakolojik etki, kation, psikolojik sekel, psikoz

Journal of Mood Disorders 2011;1(4):187-94

\section{ABSTRACT:}

Psychopharmacological aspects of catha edulis (khat) and consequences of long term use: a review

Catha edulis (khat) is a plant grown commonly in the horn of Africa. Its leaves are chewed by the local people for their stimulant action. The purpose of this review was to summarize the psychopharmacologic aspects of Catha edulis (khat) and consequences of long term use. I collected data from scientific journals. The databases such as Pubmed, Medline, Hinary, Google search, Cochrane, and Embase were searched for literature on the different aspects of Catha edulis (khat) including central nervous system effects, pharmacological effects and long term consequences of khat use. Different research findings from various sources showed that Catha edulis (khat) causes schizophreniform psychotic illness, mania, and more rarely, depression and also has negative impact on health and socio-economic conditions. Most of the effects of chewing khat come from two phenylalkylamines; cathinone and cathine which are structurally related to amphetamine. On occasion these presentations are associated with episodes of self-harm or harm to others. Owing to the mode of consumption, the dose of khat tends to be self-limiting, unlike amphetamines. Therefore toxic psychosis as a result of excessive use is much less frequent with khat than with amphetamines. Frequent khat chewing is responsible for different disorders including psychotic illness and has harmful socioeconomic consequences. It is important for clinicians to increase awareness of their patients and the general public about the harmful effects of khat-chewing.

Key words: khat, catha edulis, pharmacological effect, cathinone, psychological sequela, psychosis

Journal of Mood Disorders 2011;1(4):187-94
${ }^{1} \mathrm{BSC}, \mathrm{MSC}$ (student), Department of Pharmacy, College of Public Health, Ethiopia

Yazıșma Adresi / Address reprint requests to: Nasir Tajure Wabel, Department of Pharmacy, College of Public Health, Ethiopia

Telefon / Phone: +00251-911-68-0576

Elektronik posta adresi / E-mail address: zenastaj@yahoo.com

Kabul tarihi / Date of acceptance: 17 Aralık 2011 / December 17, 2011

Bag̃ıntı beyanı:

N.T.W. Yazarlar bu makale ile ilgili olarak

herhangi bir çıkar çatıșması bildirmemișlerdir.

Declaration of interest:

N.T.W.: The authors reported no conflict of interest related to this article.

\section{INTRODUCTION}

Khat is a natural stimulant from the Catha Edulis plant that is cultivated in mostly in East Africa. Its young buds and tender leaves (figure 1) are chewed to attain a state of euphoria and stimulation $(1,2)$. Khat is an evergreen shrub, which is cultivated as a bush or small tree. The leaves have an aromatic odour. The taste is astringent and slightly sweet. The plant is seedless and hardy, growing in a variety of climates and soils. Khat can be grown in droughts where other crops have failed and also at high altitudes. Khat is harvested throughout the year. Planting is staggered to obtain a continuous supply (3).

The khat chewers experience a sense of increased energy levels, increased alertness and ability to concentrate, improvement in self-esteem and an increase 


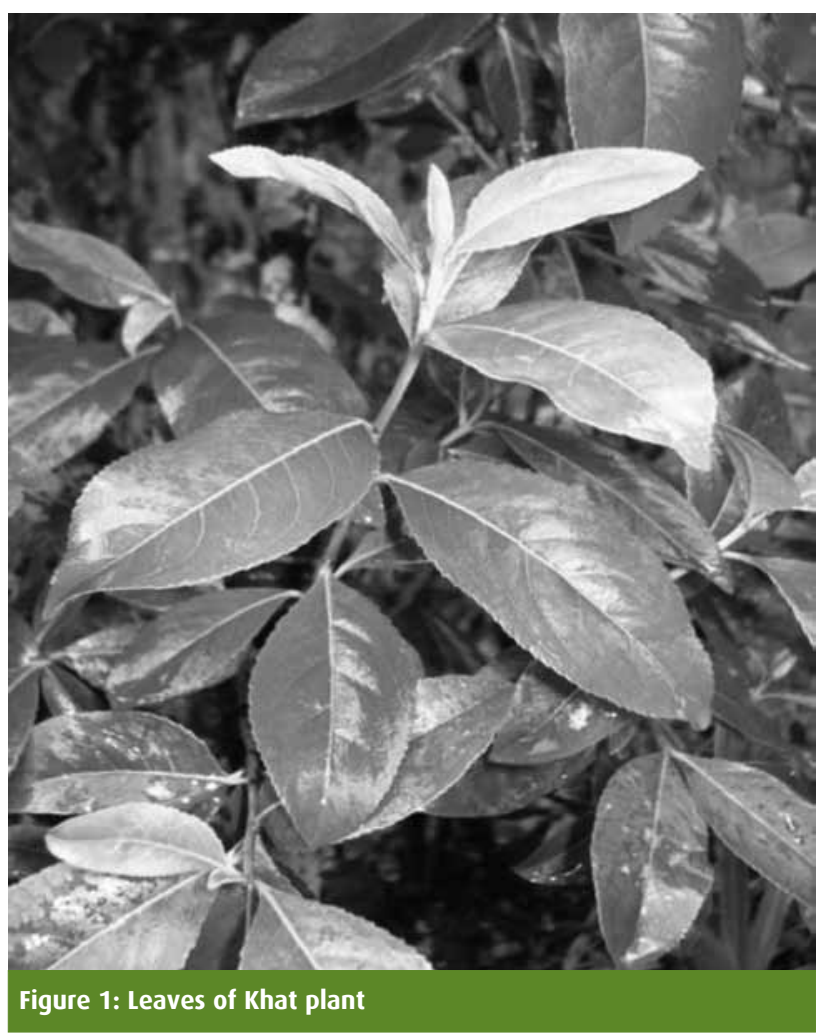

in libido (4). There is fairly extensive literature on the potential adverse effects of habitual use of khat on mental, physical, and social well-being (5). Some khat chewers experience anxiety, tension, restlessness, hypnogogic hallucinations, hypomania, and aggressive behaviour or psychosis $(6,7)$. Chronic consumption can lead to impairment in mental health, possibly contributing to personality disorders and mental deterioration $(8,9)$. Khat leaves has vasoconstrictor properties (10) that may lead to elevated blood pressure, increase in heart rate and increased incidence of acute myocardial infarction (AMI) $(11,12)$. Gastro-intestinal hazards include constipation, stomatitis, esophagitis, and gastritis (13). A significant association between the habit of khat chewing and the development of haemorrhoidal disease was reported (14). Besides damaging health, Khat has adverse socio-economic consequences and effects on many other aspects of life including the loss of thousands of acres of arable land and billions of hours of work (15).

The vast majority of those ingesting khat do so by chewing. Only a small number ingest it by making a drink from dried leaves, or, even more rarely, by smoking dried leaves. The chewer fills his or her mouth with leaves and stalks, and then chews slowly and intermittently to release the active components in the juice, which is then swallowed with saliva. The plant material is chewed into a ball, which is kept for a while in the cheek, causing a characteristic bulge (16). Khat chewing usually takes place in groups in a social setting. Only a minority frequently chew alone. A session may last for several hours. During this time chewers drink copious amounts of non-alcoholic fluids such as cola, tea, and cold water. In a khat chewing session, initially there is an atmosphere of cheerfulness, optimism, and a general sense of well-being. After about 2 hours, tension, emotional instability, and irritability begin to appear, later leading to feelings of low mood and sluggishness. Chewers tend to leave the session feeling depleted.

Chewing khat is both a social and a culture-based activity. It is said to enhance social interaction, playing a role in ceremonies such as weddings. In Yemen, Muslims are the most avid chewers. Some believe that chewing facilitates contact with Allah when praying. However, many Christians and Yemenite Jews in Israel also chew khat. Khat is a stimulant and it is used to improve performance, stay alert and to increase work capacity $(1,17)$. Workers on night shifts use it to stay awake and postpone fatigue. Students have chewed khat in an attempt to improve mental performance before exams. Yemeni khat chewers believe that khat is beneficial for minor ailments such as headaches, colds, body pains, fevers, arthritis and also depression (18).

In khat-producing African countries (19) Elmi studied khat chewers in the two main cities in Somalia: Mogadishu and Hargeisa. The results showed that traders and businessmen carried out business transactions during khat parties, whereas for the unemployed it was a way of overcoming feelings of frustration and boredom. In Somalia, Alem et al (20) found that more men habitually chewed than women: Seventy five percent of men chewed khat regularly compared to only $7-10 \%$ of women. Kennedy et al's (18) Yemen studies had similar findings. Overall, it seems that khat is less appealing to women, although in Somalia chewing has recently become more popular among middle-class and educated women. 


\section{PHARMACOLOGICAL EFFECTS OF KHAT}

\section{Active Constituents}

Khat contains more than forty alkaloids, glycosides, tannins, amino acids, vitamins, and minerals (6). The environment and climate conditions determine the chemical profile of khat leaves. In the Yemen Arab Republic, about 44 different types of khat exist originating from different geographic areas of the country $(21,22)$.

Khat contains more than 40 alkaloids, glycosides, tannins, amino acids, vitamins and minerals (23). Most of the effect of chewing khat is thought to come from two phenylalkylamines, cathinone (Figure 2) and cathine (Figure 3), which are structurally related to amphetamine (16). A number of other constituents, including cathidine, eduline and ephedrine, have been identified, but it is unlikely that any of these, except tannin, play a role in khat's effects (24).

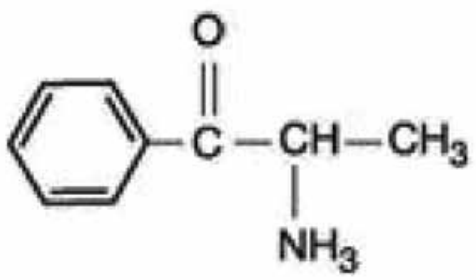

Figure 2: Chemical Structures of cathinone

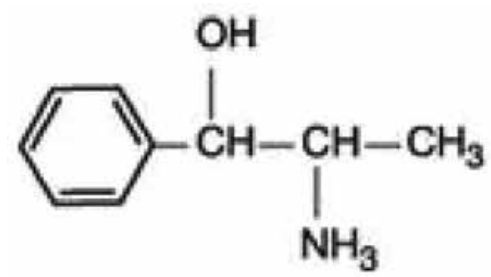

Figure 3: Chemical Structures of cathine

Cathinone is unstable and undergoes decomposition reactions after harvesting and during drying or extraction of the plant material (8,24-26). Decomposition leads to a 'dimer' (3,6-dimethyl-2,5-diphenylpyrazine) and possibly to smaller fragments. Both the dimer and phenylpropanedione have been isolated from khat extracts (26). As cathinone is presumably the main psychoactive component of khat, this explains why fresh leaves are preferred and why khat is wrapped up in banana leaves to preserve freshness.

\section{Mechanism of Action}

The constituents of khat have been shown to exert their effects on two main neurochemical pathways: dopamine and noradrenalin. It has also been postulated that, like amphetamine, cathinone releases serotonin in the central nervous system. Both cathinone and amphetamine induce release of dopamine from central nervous system dopamine terminals and thus increase the activity of the dopaminergic pathways (8). Cathinone has a releasing effect on noradrenalin storage sites, which supports the conclusion that cathinone facilitates noradrenalin transmission. Drake (27) also proposed that cathinone and cathine cause inhibition of noradrenalin uptake.

\section{Pharmacokinetics}

The effects of khat start after about 1 hour of chewing. Blood levels of cathinone start to rise within 1 hour and peak plasma levels are obtained 1.5 - 3.5 hours after the onset of chewing (28). Maximum plasma levels in this study ranged from 41-141 ng/ml (mean $83 \mathrm{ng} / \mathrm{ml}$ ) after a 1-hour chewing dose of $60 \mathrm{~g}$ fresh khat leaves per subject (cathinone: $0.8-1 \mathrm{mg} / \mathrm{kg}$ body weight). Cathinone was barely detectable at $0.5 \mathrm{~h}$ and $7.5 \mathrm{~h}$, and not detectable any more after 24 hours.

Six drug-naive male volunteers received a single khat dose of $54-71$ gram fresh leaves, corresponding to $0.8 \mathrm{mg}$ cathinone per kg body weight. Alkaloid-free khat, prepared by gentle extraction of the alkaloid fraction with 0.1 M hydrochloric acid, was used as the placebo. Chewing was for 1 hour. Maximal plasma concentrations of cathinone $(127 \pm 53 \mathrm{ng} / \mathrm{ml})$ were attained after $127 \pm 30$ minutes (values given as the mean \pm S.D.). The area under the plasma concentration-time curve from 0 to 9 hours was $415 \pm 207 \mathrm{ng} / \mathrm{ml} . \mathrm{hr}$, and the terminal elimination halflife was $260 \pm 102$ minutes (29). Comparing these values with those from an earlier study in which pure S-(-)cathinone was given to subjects, shows that the time period for reaching the maximal plasma concentration was significantly shorter (72 \pm 33 minutes) after administration of pure S-(-)-cathinone. The other values did not differ significantly (30). In humans, after oral administration of synthesized cathinone (isomers, racemate) $22-52 \%$ was recovered in $24 \mathrm{~h}$ urine samples 
mainly as the aminoalcohols, norephedrine, and norpseudoephedrine. The main metabolite of S-(-)cathinone was identified as R,S-(-)-norephedrine and the main metabolite of $\mathrm{R}-(+)$-cathinone as $\mathrm{R}, \mathrm{R}-(-)-$ norpseudoephedrine. Both aminoalcohols are apparently formed by a stereospecific keto reduction (31).

Metabolism is rapid and occurs already during first passage through the liver. Only $2 \%$ of administered cathinone was found unchanged in the urine [33]. The rate of metabolism is close to the rate of absorption, which limits cathinone blood levels reachable by chewing [9]. In humans, norephedrine and norpseudoephedrine are slowly absorbed and excreted almost unchanged in urine (32).

Recently, a pharmacokinetic study was performed with 4 volunteers and a dose of 0.6 gram of khat leaves per $\mathrm{kg}$ body weight, i.e. one fourth of a traditional khat session dose [33]. A two-compartment kinetic model with a twosegment absorption could describe the plasma concentration-time data with a tlag1 (first compartment) of 0.1-0.2 $\mathrm{h}$ and a tlag2 (second compartment) of more than $1.2 \mathrm{~h}$. The oral mucosa was seen as the first absorption segment, where the major proportion of cathinone and cathine is absorbed (mean \pm S.D.: $59 \pm 21 \%$ for cathinone; $84 \pm 6 \%$ for cathine). On the average, peak plasma levels were obtained after $2.3 \mathrm{~h}$ for cathinone, $2.6 \mathrm{~h}$ for cathine and $2.8 \mathrm{~h}$ for norephedrine. Chewing resulted in a high extraction of the alkaloids with only $9.1 \pm 4.2 \%$ remaining in the leaf residues. The mean \pm S.D. khat dose was $0.63 \pm 0.04 \mathrm{mg}$ of cathinone, $0.45 \pm 0.03 \mathrm{mg}$ of cathine, and $0.26 \pm 0.01 \mathrm{mg}$ of norephedrine per $\mathrm{kg}$ of body weight. The mean \pm S.D. terminal elimination half-life of cathinone was $1.5 \pm 0.8 \mathrm{~h}$ and that of cathine $5.2 \pm 3.4 \mathrm{~h}$. The apparent volume of the central compartment for cathinone was $2.7 \pm 1.6 \mathrm{~L} / \mathrm{kg}$ and for cathine $0.7 \pm 0.4 \mathrm{~L} / \mathrm{kg}$. The data obtained for norephedrine could be explained by the metabolism of cathinone into norephedrine (33). It has been reported that khat chewing delays gastric emptying of a semi-solid meal (34). It is not known whether this effect is caused by cathinone or by other khat constituents.

\section{Cardiovascular Effects of Khat}

Khat chewing induces small and transient rises in blood pressure and heart rate (22). Cathinone $(0.5 \mathrm{mg}$ base/kg of body weight) has similar effects coinciding with the presence of cathinone in blood plasma (31). These effects could be blocked by the betaladrenoreceptor blocker atenolol, but not by the alphaladrenorecptor blocker indoramin, indicating mediation through stimulation of betal-adrenoreceptors [59]. In a pharmacokinetic study, diastolic and systolic blood pressures were elevated for about 3 hours after chewing (33). The rise of blood pressure already started before the rise of alkaloid plasma concentrations, indicating an initial study engagement effect. The dose used was about one quarter $(0.6 \mathrm{~g} / \mathrm{kg})$ of a traditional khat session dose and chewing was for 1 hour. This resulted in a mean oral dose of $45 \mathrm{mg}$ cathinone. This rather low dose did not affect heart rate, pupil size, and reaction to light, and it did not induce rotary nystagmus or impairment of reaction. All participants reported the personal feeling of being alert and 'energetic.' An impairment of other psychophysical functions could not be objectified (33). In another study, diastolic and systolic blood pressure, mean arterial blood pressure, and heart rate were raised during the 3 hours of khat chewing and during the following hour (5). Recently, it has been reported that khat chewing is associated with acute myocardial infarction (35). Khat chewing has also been reported to be a significant risk factor for acute cerebral infarction (36). The prevalence of high blood pressure was significantly higher in the patient group than in the control group and this higher prevalence was associated with khat chewing.

\section{Central Nervous System Effects of Khat}

Chewers report their subjective experiences of khat use in a positive way when consuming small amounts. They describe a feeling of well-being, a sense of euphoria, excitement, increased energy levels, increased alertness, increased ability to concentrate, improvement in selfesteem, and an increase in libido. Also experienced are an enhanced imaginative ability and capacity to associate ideas, an improvement in the ability to communicate, and a subjective improvement in work performance. After chewing ceases, unpleasant after-effects tend to dominate the experience: insomnia, numbness, lack of concentration, and low mood. Some chewers also experience unpleasant effects during the chewing process, describing anxiety, tension, restlessness, and hypnagogic hallucinations. Objectively, chewers can be 
seen to show a range of experiences, from minor reactions to the development of a psychotic illness. Minor reactions include over-talkativeness, over activity, insomnia, anxiety, irritability, agitation, and aggression.

Broadly, the main psychiatric manifestations linked to the use of khat are a short-lived schizophreniform psychotic illness, mania (37) and, more rarely, depression (7). On occasions these presentations are associated with episodes of self-harm or harm to others. Owing to the mode of consumption, the dose of khat tends to be selflimiting, unlike amphetamines, which are available in a pure form for oral or parenteral administration. Therefore toxic psychosis as a result of excessive use is much less frequent with khat than with amphetamines.

\section{Addiction, Tolerance, and Withdrawal Effect}

Cathinone is the dependence-producing constituent of khat leaves. It is a reinforcer and maintains very high rates of responding in animal experiments (38). Debate exists as to whether khat, like amphetamines, can actually cause dependence. Some authors describe a psychological dependence rather than a physical one (23). Tolerance to khat practically does not occur; if it does, the doses are increased only very slowly. This may be due to the intrinsic properties of khat or to the physical limits on the amount that can be consumed (17).

There are conflicting opinions regarding the existence of a withdrawal syndrome. Physical withdrawal symptoms are documented, includinglassitude, anergia, nightmares, and slight trembling, which appear several days after ceasing to chew.

Depressive disorder, sedation, and hypotension are sometimes seen after withdrawal of khat. In one study only $0.6 \%$ of khat chewers continued to use in order to prevent withdrawal symptoms (20).

\section{Khat-induced Psychiatric Complications}

Most reports are of cases of psychosis and suggest a low incidence. The impression of low incidence may reflect the fact that in countries where it is most used, health facilities are lacking and people are managed at home by their family.

Dhadphale \& Omolo (9) studied psychiatric morbidity among khat users. They found that when khat was chewed in moderate quantities there was no excess morbidity, but when the amount chewed per day was greater than two bundles, morbidity was significantly increased. Other research $(39,40)$ confirms our clinical experience that adverse effects are dose-related. However, many researchers consider that khat precipitates a psychotic illness in those who are already predisposed.

Psychiatric care of these patients can be difficult, leading to less-than-optimal care. This is because patients with the 'dual diagnosis' of khat misuse and a psychotic illness are often not recognized by substance abuse treatment centers.

\section{Psychosis}

The literature outlining the characteristics of psychoses following the use of khat describes two main types: a paranoid or schizophreniform psychosis (similar to an amphetamine-induced psychosis) and a manic psychosis.

\section{Schizophreniform Psychosis}

The patients typically present with paranoid delusions, fear, a hostile perception of the environment, auditory hallucinations (frequently of a persecutory or threatening type), ideas of reference, thought alienation, and a tendency to isolate themselves, or alternatively displaying aggressive behavior towards others. If khat consumption is ceased at this time, resolution of symptoms usually occurs within a short period (3-11 days), but there is a tendency for the psychosis to recur if khat chewing is restarted.

\section{Manic Psychosis}

Several authors have described a manic-type psychosis. Giannini \& Castellani (41) reported the first case in the USA. The patient presented with hyperactivity, shouting, pressured speech, grandiose delusions with flight of ideas and tangential thought processes, and a labile mood varying from euphoria to anger. The patient had used khat for the first time, chewing about 24 leaves (this is equivalent to a single dose of khat). Symptoms subsided spontaneously within about 8 hours of ceasing chewing. Drake (27) also described a case of mania 
following prolonged chewing, with the patient 'running amok.'.

Confusional states are rare; usually the paranoid reactions occur in clear consciousness. Kennedy et al [18] stated that confusion and disorientation may occur as a transient phenomenon in the khat user, even without psychosis. Dhadphale \& Omolo (9) suggested that the people Kennedy studied were in fact exhibiting acute drug intoxication and were in a state of delirium. The level of sympathetic arousal is higher in acute khat intoxication than in heavy prolonged use, where some sympathetic tolerance occurs; this might be helpful in distinguishing between these situations (42).

\section{Impairment of Cognitive Functions and Neurological Complications}

Adverse effects of khat chewing include impairment of perceptual-visual memory and decision-speed cognitive functions (43). One case history of severe leukoencephalopathy associated with khat misuse has been reported (44). EEG and MRI findings indicated progressive leukoencephalopathy but the link with khat use is not proven and it can be just coincidence.

\section{Depression}

Several authors describe depression associated with chewing khat, but nearly these entire reports document that the depression arises after cessation of use. Depression has, on occasion, been associated with selfharm and suicide. Such behavior has also been reported following amphetamine use and cessation (7).

\section{Self-harm, Suicide and Violence}

Self-harm and suicides have been reported in the literature, although these are rare. Each has been documented during both chewing and the subsequent intoxication phase. One patient bit himself and repeatedly banged his head against the wall. Another patient took an overdose because of the distress caused by his paranoid symptoms. Suicide has been described by several authors in the context of a 'withdrawal state.'

Violent acts, including homicide, are also documented, usually in the context of paranoid or persecutory delusions. Alem \& Shibre (42) described a case where a patient murdered one of his wives and his daughter. Alem et al (20) also reported a case of combined homicide and suicide after chewing increased amounts of khat.

\section{EFFECTS OF LONG-TERM KHAT USE}

Intoxication with khat is self-limiting, but chronic consumption can lead to impairment of mental health, possibly contributing to personality disorders, and 'mental deterioration' [25]. Conversely, Dhadphale \& Omolo (9) reported no increased long-term psychiatric morbidity among khat chewers.

\section{Socio-economic Effects}

In communities where khat is used regularly it has negative impacts on health and socio-economic conditions.

\section{Decreased Productivity}

Khat chewing leads to loss of work hours, decreased economic production, malnutrition, and diversion of money in order to buy further khat. This is indirectly linked to absenteeism and unemployment, which may in turn result in a fall in overall national economic productivity. It is reported that habitual khat chewing has led to decreased productivity in Ethiopia, Somalia, Uganda, and Kenya (24). Others argue that moderate use improves performance and increases work output, owing to the stimulant and fatigue-postponing effects. Consequently, working hours and possibly productivity can decrease when khat is not used, because of anergia and reduced motivation.

\section{Family and Marital Problems}

Kalix \& Khan (36) estimated that about one-third of all wages were spent on khat in Djibouti. Many men secure their daily portion of khat at the expense of vital needs, indicating dependence. Family life is harmed because of neglect, dissipation of family income, and inappropriate behaviour. Khat is quoted as a factor in one in two divorces in Djibouti. Acquisition of funds to pay for khat may lead to criminal behaviour and even prostitution (19). 


\section{CONCLUSION}

Several studies across the globe have reported khatchewing as a harmful activity on central nervous system. Many different compounds are found in khat including alkaloids, terpenoids, flavonoids, sterols, glycosides, tannins, amino acids, vitamins, and minerals, but the major pharmacological and toxic effects stem from the phenylalkylamines. The effects on the nervous system resemble those of amphetamine. Since this is a major social issue particularly in the East Africa, raising awareness of the general public about the harmful effects of khat-chewing is important. This can be accomplished by employing appropriate communication strategies such as using printed materials, media, and electronic media.

\section{References:}

1. Lqman W, Donaldson T. The use of Khat (Catha edulis) in Yemen. Social and Medical Observations. Ann Intern Med 1976; 85:246-9.

2. Hussein M. Ageely, prevalence of khat chewing in college and secondary (high) school students of Jazan region Saudi Arabia. Harm Reduct J 2009; 6:11.

3. Luqman W, Danowski TS. The use of khat (Catha edulis) in Yemen: social and medical observations. Annals of Internal Medicine 1976 ; 85:246-249.

4. Numan N. Exploration of adverse psychological symptoms in Yemeni khat users by the Symptoms Checklist-90 (SCL 90). Addiction 2004; 99:61-5

5. Hassan NA, Gunaid AA, Abdo-Rabbo AA, et al. The effect of khat chewing on blood pressure and heart rate in healthy volunteers. Trop Doct 2000; 30:107-108.

6. George Y, Zahid H, Tim L. Khat chewing as a cause of psychosis. British Journal of Hospital Medicine 1995; 54:322-326.

7. Pantelis C, Hindler CG, Taylor JC. Use and abuse of khat (Catha edulis): a review of the distribution, pharmacology, side effects and a description of psychosis attributed to khat chewing. Pharmacological Medicine 1989; 19:657-668.

8. Kalix P, Braenden O. Pharmacological aspects of the chewing of khat leaves. Pharmacological Reviews 1985; 37:149-164.

9. Dhadphale M, Omolo OE. Psychiatric morbidity among khat chewers. East African Medical Journal 1988; 65:355-359.

10. Al-Motarreb AL, Broadley KJ. Coronary and aortic vasoconstriction by cathinone, the active constituent of khat. Auton Autacoid Pharmacol 2004; 23:319-326.

11. Al-Motarreb A, Al-Kebsi M, Al-Adhi B, Broadley KJ: Khat chewing and acute myocardial infarction. Heart 2002; 87:279-80.

12. Al-Motarreb S, Briancon N, Al-Jaber B, Al-Adhi F, Al-Jailani MS, Salek KJ. Broadley Khat chewing is a risk factor for acute myocardial infarction: a case-control study. Br J Clin Pharmacol 2004; 59:574-581.

13. Benson PB, Mcdermott W, editors: Cecil-Loeb Textbook of Medicine. $13^{\text {th }}$ edition. Philadelphia, W. B. Saunders Co 1971:107149 .

14. Al-Hadrani AM. Khat induced Haemorrhoidal disease in Yemen. Saudi Medical Journal 2000; 21:475-7.
15. Ageely HM. Health and Socioeconomic Hazards associated with Khat consumptions. Journal of Family \& Community Medicine 2008; 15:95-101

16. Nencini P, Ahmed AM, Aminconi G, et al. Tolerance develops to sympathetic effects of khat in humans. Pharmacology 1984; 28:150-154.

17. Kalix P. Khat: a plant with amphetamine effects. Journal of Substance Abuse and Treatment 1988; 5:163-169.

18. Kennedy JG, Teague J, Rokaw W, et al. A medical evaluation of the use of qat in North Yemen. Social Science and Medicine 1983; 17:783-793.

19. Elmi AS. The chewing of khat in Somalia. Journal of Ethnopharmacology 1983; 8:163-176.

20. Alem A, Kebedae D, Kullgren G. The prevalence and sociodemographic correlates of khat chewing in Butajira, Ethiopia. Acta Psychiatrica Scandinavica Supplementum 1999; 100:84-91.

21. Geisshusler S, Brenneisen R. The content of psychoactive phenylpropyl and phenylpentenyl khatamines in Catha edulis Forsk. of different origin. J Ethnopharmacol 1987; 19:269-277.

22. Al Motarreb A, Baker K, Broadley KJ. Khat: pharmacological and medical aspects and its social use in Yemen. Phytother Res 2002;16:403-413.

23. Halbach $\mathrm{H}$. Medical aspects of the chewing of khat leaves. Bulletin of the World Health Organization. 1972; 47:21-29.

24. Giannini AJ, Burge H, Shaheen JM, et al. Khat: another drug of abuse? Journal of Psychoactive Drugs 1986; 18:155-158.

25. Kite GC, Ismail M, Simmonds MS, Houghton PJ. Use of doubly protonated molecules in the analysis of cathedulins in crude extracts of khat (Catha edulis) by liquid chromatography/serial mass spectrometry. Rapid Commun Mass Spectrom 2003;17:15531564 .

26. Brenneisen R, Geisshusler S. Psychotropic drugs. III. Analytical and chemical aspects of Catha edulis Forsk. Pharm Acta Helv 1985; 60:290-301.

27. Drake PH. Khat-chewing in the Near East (letter). Lancet, i, 1988:532-533.

28. Halket JM, Karasu Z, Murray-Lyon IM. Plasma cathinone levels following chewing khat leaves (Catha edulis Forsk.). J Ethnopharmacol 1995; 49:111-113. 
29. Widler $\mathrm{P}$, Mathys $\mathrm{K}$, Brenneisen R, Kalix P, Fisch HU. Pharmacodynamics and pharmacokinetics of khat: a controlled study. Clin Pharmacol Ther 1994; 55:556-562.

30. Brenneisen R, Fisch HU, Koelbing U, Geisshusler S, Kalix P. Amphetamine-like effects in humans of the khat alkaloid cathinone. Br J Clin Pharmacol 1990; 30:825-828.

31. Brenneisen R, Geisshusler S, Schorno X. Metabolism of cathinone to (-)-norephedrine and (-)-norpseudoephedrine. J Pharm Pharmacol 1986; 38:298-300.

32. Maitai CK, Mugera GM. Excretion of the active principle of of Catha edulis (Miraa) in human urine. J Pharm Sci 1975; 64:702703.

33. Toennes SW, Harder S, Schramm M, Niess C, Kauert GF. Pharmacokinetics of cathinone, cathine and norephedrine after the chewing of khat leaves. Br J Clin Pharmacol 2003; 56:125-130.

34. Heymann TD, Bhupulan A, Zureikat NE, Bomanji J, Drinkwater C, Giles P, Murray-Lyon IM. Khat chewing delays gastric emptying of a semi-solid meal. Aliment Pharmacol Ther 1995; 9:81-83.

35. Alkadi HO, Noman MA, Al Thobhani AK, Al Mekhlafi FS, Raja'a YA. Clinical and experimental evaluation of the effect of Khat-induced myocardial infarction. Saudi Med J 2002; 23:1195-1198.

36. Kuczkowski KM. Herbal ecstasy: cardiovascular complications of khat chewing in pregnancy. Acta Anaesthesiol Belg 2005; 56:19-21.
37. Yousef G, Huq Z, Lambert T. Khat chewing as a cause of psychosis. British Journal of Hospital Medicine 1995; 54:322-326.

38. Kalix P, Khan I. Khat: an amphetamine-like plant material. Bulletin of the World Health Organization 1984; 62:681-686.

39. Critchlow S, Seifert R. Khat-induced paranoid psychosis. British Journal of Psychiatry 1987; 150:247-249.

40. Alem A, Shibre T. Khat induced psychosis and its medico-legal implication: a case report. Ethiopian Medical Journal 1997; 35:137141.

41. Giannini AJ,Castellani S. A manic-like psychosis due to khat (Catha edulis Forsk). Journal of Clinical Toxicology 1982; 19:455459.

42. McLaren P. Khat psychosis (letter). British Journal of Psychiatry $1987 ; 150,712-713$.

43. Khattab NY, Amer G. Undetected neuropsychophysiological sequelae of khat chewing in standard aviation medical examination. Aviat Space Environ Med 1995; 66:739-744.

44. Morrish PK, Nicolaou N, Brakkenberg P, Smith PE. Leukoencephalopathy associated with khat misuse. J Neurol Neurosurg Psychiatry 1999; 67:556. 